\title{
PENINGKATAN KECERDASAN KINESTETIK MELALUI TARI KREATIF UNTUK ANAK USIA 5-6 TAHUN DI TAMAN KANAK-KANAK ASSAID LARANGAN
}

\author{
Loveita Meitarini \\ Taman Kanak-kanak Assaid Larangan, Tangerang, Banten \\ email: vitaloveitameitarini@gmail.com
}

\begin{abstract}
This study aims to determine whether creative dance activities (Sundanese Sundanese) can improve kinesthetic intelligence in children aged 5-6 years in the Assaid Kindergarten Prohibition. Classroom action model (CAR) or classroom action research with research subjects consisting of 14 students, 8 boys and 6 girls. As per the results of the data obtained in the research carried out in the Assaid Kindergarten the prohibition of the percentage of children's kinesthetic intelligence in the Assaid Kindergarten Prohibition before the action is carried out is 35\%. The target set by researchers and collaborators is $75 \%$. After the action was implemented, it showed an increase in cycle 1 when compared to the pre cycle, which was $68 \%$. However, because the results obtained are not yet in line with the eating target implemented in the second cycle and the results have increased by $90 \%$. So this research can be declared successful. These results indicate compliance with the action hypothesis that is kinesthetic intelligence of children aged 5-6 years in Assaid Kindergarten Prohibition can be increased through creative dance (Sundanese Sundanese).
\end{abstract}

Keywords: Kinesthetic intelligence, creative dance, Sundanese Papua, children aged 5-6 years

\begin{abstract}
Abstrak
Penelitian ini bertujuan untuk mengetahui apakah kegiatan tari kreatif (sunda papua) dapat meningkatkan kecerdasan kinestetik pada anak usia 5-6 tahun di Taman Kanak-Kanak Assaid Larangan. Model tindakan kelas (PTK) atau classroom action research dengan subjek penelitian yang terdiri dari 14 siswa yaitu 8 anak laki-laki dan 6 anak perempuan. Sesuai hasil data yang diperoleh pada penelitian yang dilaksanakan di Taman Kanak-Kanak Assaid Larangan persentase kecerdasan kinestetik anak di Taman Kanak-Kanak Assaid Larangan sebelum dilakukan tindakan yaitu sebesar 35 $\%$. Adapun target yang ditetapkan oleh peneliti dan kolaborator adalah sebesar $75 \%$. Setelah dilaksanakan tindakan menunjukkan peningkatan pada siklus 1 jika dibandingkan dengan pra siklus yaitu sebesar $68 \%$. Namun, karena hasil yang didapat belum sesuai dengan target makan dilaksanakan siklus II dan hasilnya mengalami peningkatan sebesar yaitu $90 \%$. Sehingga penelitian ini dapat dinyatakan berhasil. Hasil tersebut menunjukkan kesesuaian dengan hipotesis tindakan yaitu kecerdasan kinestetik anak usia 5-6 tahun di Taman Kanak-Kanak Assaid Larangan dapat ditingkatkan melalui tari kreatif (sunda papua).
\end{abstract}

Kata Kunci: Kecerdasan kinestetik, tari kreatif, Sunda Papua, anak usia 5-6 tahun

\section{PENDAHULUAN}

Masa usia dini merupakan masa terjadinya kematangan fungsi-fungsi fisik dan psikis yang siap merespon stimulasi (rangsangan) yang diberikan oleh lingkungan. Masa ini merupakan masa untuk meletakkan dasar pertama dalam mengembangkan potensi fisik (motorik), intelektual, emosional, sosial, bahasa, seni dan moral spiritual.
Secara alamiah, perkembangan anak berbeda-beda, baik secara intelegensi, bakat, minat, kreativitas, kematangan emosi, kepribadian, jasmani dan sosialnya dan anak sudah dapat menggunakan otototot kakinya untuk berjalan sebelum anak mampu mengontrol tangan dan jari-jarinya untuk menggambar atau menggunting.

Keterampilan mengkoordinasikan pikiran dan organ tubuh dalam bentuk 
berbagai gerakan mampu memperkuat rasa kepercayaan diri pada anak-anak, sehingga tertanam dalam hati mereka bahwa dirinya sanggup melakukan pekerjaan apapun dengan hasil yang terbaik.Akan tetapi pembelajaran di TK belum mengembangkan kecerdasan kinestetiknya yang diantaranya anak selalu berpaku pada duduk rapi di dalam kelas dan mengerjakan lembar kerja yang di berikan oleh gurunya, serta anak jarang melakukan kegiatan yang menggunakan gerak tubuhnya.

Pada penelitian ini peneliti mengambil tarian dengan musik sabilulungan yang digabungkan dengan lagu yamko rambe yamko. Peneliti memilih lagu ini dikarenakan pada anak usia dini jarang diajarkan lagu sabilulungan oleh karena itu peneliti ingin mengenalkan musik sabilulungan tersebut yang berasal dari sunda yan digabungkan dengan musik yamko rambe yamko yang berasal dari papua. Irama tempo musik sabilulungan yaitu slow atau pelan dan tempo musik yamko rambe yamko adalah gembira atau riang. Jadi tarian ini menggabungkan tarian yang musiknya bertempo pelan dan gembira atau riang. Pembelajaran tari kreatif (Sunda Papua) merupakan sebuah kegiatan dalam bermain sambil belajar dan belajar sambil bermain, aktivitas yang dilakukan melalui kegiatan tari kreatif (Sunda Papua) diharapkan akan menyenangkan anak sekaligus untuk meningkatkan/mengembangkankemampua $\mathrm{n}$ mengolah dan mengontrol gerakan tubuh. Dengan bernyanyi dan bergerak sesuai dengan lagu dapat menyalurkan, mengendalikan dan menselaraskan antara pikiran dan tubuh (koordinasi tubuh), mengembangkan kelincahan, kekuatan, dankeseimbangan tubuh serta mengkoordinasikan mata dengan tangan dan kaki.

Uraian di atas menunjukkan bahwa penting bagi para guru untuk membantu mengembangkan kecerdasan kinestetik pada anak. Hal inilah yang membuat penulis tertarik untuk mengadakan penelitian dengan judul "Meningkatkan Kecerdasan Kinsetetik Anak Usia 5 - 6 Tahun Melalui Tari Keatif di Taman Kanak-Kanak Assaid LaranganTangerang."

Berdasarkan fokus penelitian tersebut di atas, maka penulis merumuskan masalah yang akan menjadi fokus dari perbaikan pembelajaran yaitu:

1. Apakah kecerdasan kinestetik dapat ditingkatkan melalui tari kreatif pada anak usia 5-6 tahun di Taman Kanakkanak Assaid, Larangan?

2. Bagaimanakah penerapan tari kreatif dalam meningkatkan kecerdasan kinestetik pada anak usia 5-6 tahun di Taman Kanak-kanak Assaid, Larangan?

Berdasarkan rumusan masalah diatas maka tujuan penelitian adalah Untuk menemukan bagaimana cara meningkatkan kecerdasan kinestetik melalui tari kreatif anak usia 5-6 tahun, sehingga anak dapat termotivasi untuk menggerakkan tubuhnya, bertepuk tangan, menari, atau menghentakkan kaki mengikuti musik yang melatih mereka untuk mengontrol tubuhnya.

\section{KAJIAN LITERATUR Kecerdasan Kinestetik}

Kecerdasan memiliki pengertian yang sama dengan intelegensi. Menurut Williem dalam Ngalim Purwanto (2007: 52), inteligensi ialah suatu kesanggupan untuk menyesuaikan diri kepada kebutuhan baru, dengan menggunakan alat berpikir yang sesuai dengan tujuannya, dan inteligensi tersebut sebagian besar tergantung dengan dasar dan turunan.

Menurut Gardner multiple Intelligence adalah sebuah penilaian yang melihat secara deskriptif bagaimana individu menggunakan kecerdasannya untuk memecahkan masalah dan menghasilkan sesuatu (Yuliani, 2009:183).

Seorang anak akan menjadi penyejuk hati (qurrota a'yun) jika dia tumbuh 
menjadi anak yang taat kepada Allah SWT, tekun beribadah, menjalankan perintah-perintah Allah AWT dan Rasulnya serta menjauhi segala laranganNya dan diharamkan-Nya. (Kusmayadi, 2011:1).

Kecerdasan pada anak usia dini muncul pada saat tertentu sesuai irama perkembangannya seperti yang dikemukakan oleh Piaget yang mengartikan kecerdasan adalah seluruh kemampuan berpikir dan bertindak secara adaptif, termasuk kemampuan mental yang kompleks seperti berpikir, mempertimbangkan, menganalisis, mensiotesis, mengevaluasi dan menyelesaikan persoalan-persoalan. (Ngalim Purwanto, 2007: 52)

Berdasarkan pendapat di atas dapat disimpulkan bahwa kecerdasan merupakan kesanggupan untuk menyesuaikan diri dan keseimbangan serta integritas intelektual yang berkaitan dengan semua bagian otak terutama otak kanan dan otak kiri.

Menurut Howard Gardner (2001: 3) kecerdasan kinestetik adalah kemampuan dalam menggunakan seluruh tubuh untuk mengekspresikan ide-ide dan perasaanperasaan atau menggunakan tangan-tangan untuk menghasilkan dan mentransformasikan sesuatu. Kecerdasan ini mencakup keahlian-keahlian fisik khusus seperti koordinasi, keseimbangan, ketangkasan, kekuatan, kelenturan dan kecepatan.

Kecerdasan gerak-kinestetik berkaitan dengan kemampuan menggunakan gerak seluruh tubuh untuk mengekspresikan ide dan perasaannya serta keterampilan mempergunakan tangan untuk mencipta atau mengubah sesuatu. Kecerdasan ini meliputi kemampuan fisik yang spesifik, seperti koordinasi, keseimbangan, keterampilan, kekuatan, kelenturan, kecepatan dan keakuratan menerima rangsang, sentuhan, dan tekstur. (Tadkiroatun Musfiroh, 1998: 50-51).

Kecerdasan kinestetik adalah kerjasama tubuh untuk mencapai tujuan tertentu, yang mengombinasikan interpretasi mental dengan respons fisik. Keterampilan mengkoordinasikan pikiran dan organ tubuh dalam bentuk berbagai gerakan akan mampu memperkuat rasa kepercayaan diri pada anak-anak, sehingga tertanam dalam hati mereka bahwa dirinya sanggup melakukan pekerjaan apapun dengan hasil yang terbaik. (Igrea Siswanto, 2008: 118).

Berdasarkan uraian diatas maka dapat disimpulkan bahwa kecerdasan kinestetik adalahkemampuan dalam menggunakan keseluruhan potensi tubuh untuk mengekspresikan ide-ide dan perasaan. Memiliki kemampuan untuk menggunakan tangan untuk memproduksikan atau mentransformasikan benda.

\section{Kecerdasan Kinestetik Anak Usia 5-6 Tahun}

Kecerdasan kinestetik pada anak usia 5-6 tahun dapat dikembangkan melalui bermacam-macam kegiatan, seperti bermain peran, mendongeng, pantonim, dan menari. Menurut Yuliani (2012:65) ciri perkembangan fisik anak usia 5-6 tahun diantaranya mampu melompat dengan kaki yang saling bergantian, mampu melempar dengan wajar dan teliti, dapat meningkatkan perkembsngan otot yang kecil dan koordinasi mata dan tangan yang berkembang baik, melakukan putaran dan berjungkit.

Berdasarkan pendapat di atas dapat disimpulkan bahwa ciri-ciri kecerdasan kinestetik mampu melompat dengan kaki yang saling bergantian, mampu melempar dengan wajar dan teliti, dapat meningkatkan perkembsngan otot yang kecil dan koordinasi mata dan tangan yang berkembang baik, melakukan putaran dan berjungkit, mampu menjaga keseimbangan badan ketika sedang berjalan diatas papan titian (papan kecil yang menyerupai jembatan tanpa adanya pegangan), mampu melakukan senam dengan gerakan, mampu melompat dengan satu kaki atau dua kaki, dapat memakai baju (kaos) dan sepatu 
secara sederhana (tanpa tali) sendiri tanpa dibantu oleh orang lain, mampu melakukan acrobat, dan mampu menggunting kertas dan menempelkannya.

\section{Pembelajaran Tari Kreatif}

Dance atau Tari merupakan salah satu cabang seni yang menggunakan gerak dan tubuh manusia sebagai alat ekspresi (Tim Estetika, 2000: 90). Menurut Curt Sach dalam (Widia Pekerti,dkk, 2008: 5.3) bahwa tari adalah gerak tubuh yang ritmis. Dalam tari, gerak tubuh manusia dipakai sebagai sarana mengungkapkangagasan, perasaan, dan pengalaman seniman kapada orang lain maka tidak mengherankan apabila dikatakan bahwa tari menjadi salah satu bahasa komunikasi seniman. Dan Soedarsono menjelaskan bahwa tari adalah desakan perasaan manusia tentang sesuatu yang disalurkan melalui gerak-gerak ritmis yang indah.

Tari dalam artian yang sederhana adalah gerak yang indah dan lahir dari tubuh yang bergerak dan berirama. (Novi Mulyani, 2016:49). Semua gerak disekitar kita dapat menjadi sumber gagasan gerak tari, misalnya gerakan manusia ketika sedang bekerja atau bermain, gerak tumbuh-tumbuhan, gerak hewan, gerak benda-benda buatan manusia seperti mobil, mesin, dan robot). Agar dapat menjadi gerak tari, gerak tersebut harus diolah baik dari aspek tenaga, ruang, maupun waktunya, sehingga hasilnya bukan semata-mata menirukan gerak yang nyata. Proses ini disebut proses penghalusan dan proses perombakan gerak. (Widia Pekerti, dkk, 2008: 5.3).

Tari adalah gerakan badan (tangan dan sebagainya) yang berirama dan biasanya diiringi bunyi-bunyian (musik, gamelan, dsb) (Kamus Besar Bahasa Indonesia, 1988: 414). Berdasarkan pendapat di atas dapat disimpulkan bahwa tari merupakan seni yang menggunakan gerak dan tubuh manusia untuk mengungkapkan gagasan, perasaan, dan pengalaman seniman kapada orang lain yang berirama dan biasanya diiringi bunyi-bunyian (musik, gamelan, dsb).

\section{Tari Kreasi Sabilulungan dan Yamko Rambe Yamko}

Tari kreasi, atau disebut juga tari kreasi baru merupakan tari yang telah mengalami pengembangan atau bertolak dari pola-pola tari yang sudah ada sebelumnya. Trai kreasi baru merupakan garapan baru yang mempunyai kebebasan dalam mengungkapkan gerak. Dalam hal ini, gerakan tari kreasi baru ada yang berpijak pada pola-pola yang sudah ada (tradisi), ada pula yang tidak berpijak pada pola-pola yang ada, atau benar-benar gerakan baru yang kreatif.

Sabilulungan artinya gotong royong. Sabibilungan merupakan lagu Sunda yang termasuk dalam kategori kawih. Dalam seni Sunda, terdapat beberapa jenis lagu, seperti kawih, kakawihan dan tembang. Kawih adalah lagu Sunda bebas yang tidak terikat oleh aturan. Lirik yang ada dalam kawih mirip seperti sajak, yaitu bentuk puisi yang tidak terikat oleh aturan.

Kawih Sabilulungan diciptakan oleh Koko Kosawara, yang akrab dipanggil Mang Koko. Mang Koko yang berprofesi sebagai seniman, budayawan, pangajar dan wartawan tersebut, lahir di Kecamatan Indihiang, Kabupaten Tasikmalaya, 10 April 1917. Mang Koko adalah merupakan seniman Sunda yang menghasilkan banyak karya-karya seni Sunda. Makna, isi atau amanat dari kawih sabilulungan adalah bahwa sabilulungan yang memiliki arti yakni saling tolong menolong atau seia sekata, adalah merupakan dasar dalam melakukan gotong royong atau kerja sama. Dengan adanya sabilulungan tersebut, maka akan ada kebersamaann dalam hidup, saling menyayang, saling membantu, yang pada akhirnya akan dapat memperkokoh persatuan.

Sedangkan yamko rambe yamko adalah judul lagu daerah yang berasal dari Provinsi Papua, Indonesia. Meskipun irama lagu ini menggambarkan kesan 
menyenangkan, sebenarnya arti syair lagunya menceritakan kesedihan akibat peperangan, utamanya pertikaian dan perlawanan bangsa Indonesia terhadap para penjajah yang terjadi sebelum tahun 1945.

(https://id.wikipedia.org/wiki/Yamko_Ram be Yamko ).

Di dalam tari ini, pelantun lagu ingin menjadi bunga bangsa. Bunga bangsa yang dimaksud adalah pahlawan yang rela berkorban, bahkan sampai mati, untuk mempertahankan negara Indonesia ini dari para

\section{(https://brainly.co.id/tugas/186169).} penjajah.

Jadi tari sabilulungan dan yamko rambe yamko merupakan jenis tarian kreasi yang menggunakan musik lagu daerah sunda yang di gabungkan dengan musik dari daerah papua.

\section{Langkah Kegiatan Pembelajaran}

Berikut ini adalah langkah-langkah kegiatan pembelajaran sabilulungan mix yamko rambe yamko dance yang melibatkan anak peserta didik di kelas :

1. Langkah Pertama

Menggerakkan tangan ke samping atas kanan dan samping kiri secara bergantian

2. Langkah Kedua

Tangan di pinggang kemudian pinggul di goyang ke kanan dan ke kiri secara bergantian kemudian duduk

3. Langkah Ketiga

Menggerakkan tangan ke samping kanan dan samping kiri secara bergantian

4. Langkah Keempat

Berdiri sambil mengambil wadah yang berisi bunga kemudian bunga tersebut di lempar sambil berputar.

5. Langkah Kelima

Ambil bambu yang telah disiapkan, kemudian memukul bambu secara berirama dan bergantian

6. Langkah Keenam

Mengayunkan tangan dengan posisi mengepal sambil memegang bambu ke belakang dan ke depan

\section{Langkah Ketujuh}

Memukul bambu secara bergantian ke atas kanan dan kiri kemudian ke bawah kanan dan kiri

8. Langkah Kedelapan

Mengangkat kedua tangan ke atas dan ke bawah sambil membungkukkan badan ke bawah

\section{METODE PENELITIAN}

Penelitian ini menggunakan model tindakan kelas (PTK) atau classroom action research. Sudaryono (2014: 65) mengartikan bahwa penelitian tindakan kelas adalah penelitian yang dilakukan pada sebuah kelas untuk mengetahui akibat tindakan yang diterapkan pada suatu subyek penelitian di kelas tersebut. Sementara Arikunto (2006: 3) mengemukakan bahwa penelitian tindakan kelas merupakan suatu pencermatan terhadap kegiatan belajar berupa sebuah tindakan yang sengaja dimunculkan dan terjadi pada sebuah kelas secara bersama.

Sedangkan menurut Rapoport (1970, dalam hopkins, 1993) mengartikan peneltian tindakan kelas untuk membantu seseorang dalam mengatasi secara praktis persoalan yang dihadapi dalam situasi darurat dan membantu pencapaian tujuan ilmu sosial dengan kerjasama dalam kerangka etika yang disepakati bersama (Wiriatmaja, 2010: 11-12).

Mengingat penelitian ini merupakan penelitian tindakan, maka metode yang digunakan oleh peneliti dalam melakukan penelitian ini adalah metode penelitian tindakan kelas. Penelitian Tindakan Kelas (PTK) adalah kegiatan mengumpulkan, mengolah, menganalisis dan menyimpulkan data untuk menentukan tingkat keberhasilan jenis tindakan yang dilaksanakan oleh guru dalam proses pembelajaran (Yuliawati, 2012: 17)

Penelitian Tindakan Kelas (PTK) merupakan laporan dari kegiatan nyata yang dilakukan para guru di kelasnya dalam upaya meningkatkan mutu pembelajaran. Dengan melakukan kegiatan 
Penelitian Tindakan Kelas (PTK) para guru telah melakukan salah satu tugasnya dalam kegiatan pengembangan profesi.

Dari beberapa macam model penelitian tindakan kelas yang ada, peneliti memilih untuk melakukan model penelitian tindakan kelas yang dikembangkan oleh Kemmis \& McTaggart. Model Penelitian Tindakan Kelas yang dikembangkan oleh Kemmis \& McTaggart merupakan pengembangan model Penelitian Tindakan Kelas yang diperkenalkan oleh Kurt Lewin, yang menyatakan ada 4 konsep pokok dalam penelitian tindakan yaitu terdiri perencanaan (Planning), tindakan (Acting), Ppngamatan (Observing) dan refleksi (Reflecting)

\section{Teknik Analisis Data}

Setelah peneliti selesai melakukan pengolahan data, maka langkah selanjutnya adalah menganalisis data yang telah diperoleh. Analisis data merupakan hal yang sangat penting bagi penelitian, karena dengan melakukan analisis data semua data yang telah diperoleh dapat mempunyai arti/makna yang berguna dalam memecahkan masalah penelitian.

Menurut Supardi analisis data ialah proses mengorganisasikan data ke dalam pola dan kategori (Supardi, 2008: 131). Penelitian tindakan yang dilakukan peneliti, meiputi dua data yaitu data kualitatif dan data kuantitatif . Menurut Moleong, data yang bersifat kuantitatif terdiri dari hasil observasi dan dokumentasi dianalisis secara deskriptif dan kualitatif.

Sedangkan data kualitatifnya adalah data yang berwujud angka (Sudijono, 2009: 12), yang diperoleh dari hasil observasi dan analisis data berdasarkan lembar instrumen yang berisi beberapa indikator yang akan dicapai sehingga dapat memberikan gambaran mengenai kecerdasan kinestetik pada anak kelompok B.
Rumus yang digunakan untuk menghitung nilai rata-rata dan nilai presentase sebagai berikut:

1). Nilai rata-rata

Nilai rata-rata ini didapat menggunakan rumus sebagai berikut:

\begin{tabular}{l|}
$\mathrm{X}=\Sigma \mathrm{x}$ \\
$\Sigma \mathrm{n}$
\end{tabular}

Keterangan: $X=$ Nilai rata-rata anak $\Sigma \mathrm{x}=$ Jumlah nilai anak

diteliti $\Sigma \mathrm{n}=$ Jumlah aspek yang

2). Presentase nilai individu

$$
\mathrm{n}=\mathrm{f} \times 100 \%
$$

$$
\begin{array}{ll}
\text { Keterangan : } & \mathrm{P}=\text { Presentase } \\
\mathrm{f}=\text { Rata-rata nilai anak } \\
\mathrm{n}=\text { Kriteria nilai tertinggi }
\end{array}
$$

\section{HASIL DAN PEMBAHASAN}

Sebelum dilakukan kegiatan siklus I peneliti terlebih dahulu melakukan kegiatan pra-penelitian atau pra siklus. Kegiatan pra siklus dilakukan untuk mengumpulkan data-data mengenai anak yang akan diteliti melalui observasi langsung dengan dibantu oleh kolabolator yaitu guru kelas yang dilaksanakan sebanyak 2 kali pertemuan, yaitu pada tanggal 11-13 Desember 2016. Jadwal penelitian di sekolah dilaksanakan 3 hari dalam seminggu mulai pukul $08.00 \mathrm{~s} / \mathrm{d}$ 10.00 WIB. Peneliti melakukan observasi kepada anak-anak serta melakukan tanya jawab yang bertujuan untuk melihat proses belajar anak sekaligus mengetahui peningkatan kecerdasan kinestetik anak.

Berdasarkan data yang disajikan dapat dilihat bahwa hasil pada tahap pra sikus kecerdasan kinestetik anak di kelas B KBTK Assaidadalah 35\%, hasil tersebut masih kurang dan masih perlu ditingkatkan sehingga perlu dilakukan tindakan lebih lanjut. Berdasakan hasil observasi maka 
dari itu peneliti bersama dengan kolabolator melakukan diskusi untuk meningkatkan kecerdasan kinestetik pada anak kelompok B.

\section{Siklus I}

\section{a. Perencanaan}

Dalam tahap perencanaan tindakan, peneliti menyusun rancangan tindakan yang akan diberikan sebagai berikut:

1) Membuat rencana pelaksanaan pembelajaran untuk pelaksanaan tindakan pada siklus 1 Rencana tindakan yang akan dilaksanakan adalah pengenalan lagu yamko rambe yamko.

2) Mempersiapkan media yang akan digunakan.

3) Membuat instrument pemantauan tindakan berupa lembar observasi serta menyiapkan buku catatan untuk menulis hasil catatan lapangan yang akan dijadikan alat tes disetiap akhir pertemuan siklus.

4) Memberikan lembar pengamatan dan observasi kepada kolabolator.

\section{b. Pelaksanaan}

Tahap pelaksanaan siklus I dilaksanakan pada hari Senin, 16 Januari 2017. Pelaksanaan penelitian dilakukan langsung oleh peneliti dengan guru pendamping sebagai observer.Pelaksanaan penelitian diawali dengan berdoa dan menyanyikan lagu anak. Kemudian guru melakukan kegiatan bercakap-cakap dengan anak-anak mengenai tema yang sedang berlangsung hari itu. Pada tahap ini peneliti melaksanakan kegiatan menggerakkan tangan secara bersamaan ke samping kanan dan kiri sesuai irama musik, menggerakkan pinggul ke kanan dan ke kiri sesuai dengan rencana kegiatan yang ditelah dibuat dan disepakati sebelumnya. Kemudian peneliti memberikan arahan mengenai kegiatan yang akan dilaksanakan pada hari itu, peneliti juga memberitahu terlebih dahulu kepada anak-anak mengenai gerakan awal dalam tarian lagu sabilulungan.
Diakhirpembelajaran peneliti melakukan evaluasi dengan cara melakukan tanya jawab dengan anak-anak mengenai kegiatan yang telah dilakukan. Setelah itu dilanjutkan dengan bernyanyi, berdo'a, memberi salam dan pulang.

Tahap pelaksanaan siklus I pertemuan kedua dilaksanakan pada hari Kamis, 19 Januari 2017. Pelaksanaan penelitian dilakukan langsung oleh peneliti dengan guru pendamping sebagai observer. Pelaksanaan penelitian diawali dengan berdoa dan menyanyikan lagu anak. Kemudian guru melakukan kegiatan bercakap-cakap dengan anak-anak tentang tema. Pada tahap ini peneliti melaksanakan kegiatan membuat lingkaran secara bersama sama, melakukan gerakan memukul bambu sesuai dengan rencana yang ditelah dibuat dan disepakati.

Di akhir pembelajaran peneliti melakukan diskusi dengan anak-anak mengenai kegiatan yang telah dilakukan. Setelah itu dilanjutkan dengan bernyanyi, berdo'a, memberi salam dan pulang.

Tahap pelaksanaan siklus I pertemuan ketiga dilaksanakan pada hari Jumat, 20 Januari 2017. Pelaksanaan penelitian dilakukan langsung oleh peneliti dengan guru pendamping sebagai observer. Pelaksanaan penelitian diawali dengan berdoa dan menyanyikan lagu. Kemudian guru melakukan kegiatan bercakap-cakap tentang tema dengan anak-anak.Pada tahap ini peneliti melakukan memberikan contoh tiga gerakan pada lagu sabilulungan kemudian peneliti menugaskan kepada anak untuk melakukan gerakan tersebut diantaranya melakukan gerakan pundak ke kanan dan ke kiri, menggerakkan tangan ke samping kanan dan kiri secara bergantian, menggerakkan pinggul ke kanan dan ke kiri secara bergantian. Hal ini dilakukan untuk mengukur kemampuan anak.

Di akhir pembelajaran peneliti melakukan diskusi dengan anak-anak mengenai kegiatan yang telah dilakukan. 
Setelah itu dilanjutkan dengan bernyanyi, berdo'a, memberi salam dan pulang.

\section{c. Observasi}

Observasi pada siklus I ini berpedoman pada lembar observasi yang telah disusun. Berdasarkan hasil observasi maka dapat terlihat bagaimana keadaan anak-anak saat melakukan kegiatan tersebut. Berdasarkan observasi yang telah dilakukan terdapat masih banyak hasil yang belum sesuai dengan harapan. Hal ini menunjukkan bahwa penelitian pada siklus I pertemuan ketiga belum berhasil, meskipun terlihat sudah adanya peningkatan dari pertemuan sebelumnya.

\section{d. Refleksi}

Dengan melihat hasil akhir dari siklus I ini dan berdasarkan pengamatan serta diskusi dengan kolabolator, maka kegiatan yang dilaksanakan pada siklus I pertemuan ketiga ini masih belum berhasil.

Berdasarkan data yang disajikan diatas bisa dilihat bahwa hasil pada tahap pra sikus kecerdasan kinestetik anak di kelas B KB-TK Assaidadalah 68\%, hasil tersebut masih kurang dan masih perlu ditingkatkan sehingga perlu dilakukan tindakan lebih lanjut. Skor yang diperoleh dari data hasil observasi kecerdasan kinestetikanak pada siklus I terhadap 14 responden secara keseluruhan didapat skor maksimum 79\% skor minimum $41 \%$ yang diperoleh.Dari data hasil observasi kecerdasan kinestetik anak di siklus I tersebut dapat dilihat dalam bentuk tabel sebagai berikut:

\section{Siklus II}

Melihat hasil dari tindakan Siklus I, maka peneliti mulai melakukan tindakan siklus II. Pelaksanaan tindakan siklus II pada minggu ke 4 bulan Januari 2017.

\section{a. Perencanaan}

Pada pertemuan ini peneliti masih melakukan kegiatanprkatek kegiatan sabilulungan mix yamko rambe yamko dance. Peneliti mempersiapkan tape dan lagu tarian sabilulungan yang digabungkan dengan musik yamko rambe yamko sebagai media kegiatan hari ini. Peneliti juga memberikan lembar observasi kepada kolaborator sebagai observer untuk dilakukan penilaian.

\section{b. Pelaksanaan}

Kegiatan diawali dengan berdo'a, salam dan pemberian motivasi oleh peneliti. Kemudian seperti biasa melakukan kegiatan bercakap-cakap tentang tema pada hari itu. Sebelum memulai kegiatan, peneliti terlebih dahulu membahas tema, kemudian selanjutnya peneliti menertibkan posisi menari anakanak.

Pertemuan pertama pada siklus II ini, dilakukan pada Senin, 23 Januari 2017.Pada tahap ini peneliti melakukan penjelasan tentang gerakan tarian sesuai dengan rencana kegiatan yang ditelah dibuat dan disepakati sebelumnya. Kemudian peneliti memberikan arahan mengenai kegiatan yang akan dilaksanakan pada hari itu diantaranya gerakan mengangkat tangan ke atas dan ke bawah sambil mrmbungkukkan badan, Menggerakkan pinggul ke kanan dan ke kiri secara bergantian. mengikuti lagu yamko rambe yamko, menghentakkan kedua kaki secara bergantian, peneliti juga memberitahu terlebih dahulu kepada anakanak urutan gerakan tarian. Selanjutnya peneliti melakukan tanya jawab kegiatan yang dilakukannya.

Diakhir pembelajaran peneliti melakukan evaluasi dengan cara melakukan tanya jawab dengan anak-anak mengenai kegiatan yang telah dilakukan. Setelah itu dilanjutkan dengan bernyanyi, berdo'a, memberi salam dan pulang.

Tahap pelaksanaan siklus I pertemuan kedua dilaksanakan pada hari Kamis, 26Januari 2017. Pelaksanaan penelitian dilakukan langsung oleh peneliti dengan guru pendamping sebagai observer. Pelaksanaan penelitian diawali dengan berdoa dan menyanyikan lagu. Kemudian guru melakukan kegiatan bercakap-cakap tentang tema dengan anak-anak.Pada tahap ini peneliti melaksanakan kegiatan gerakan tarian sesuai dengan rencana kegiatan yang 
ditelah dibuat dan disepakati sebelumnya. Kemudian peneliti memberikan arahan mengenai kegiatan yang akan dilaksanakan pada hari itu, peneliti juga memberitahu terlebih dahulu kepada anak-anak urutan gerakan tarian. Selanjutnya peneliti melakukan tanya jawab kegiatan yang dilakukannya dan anak-anak melakukan gerakan tersebut dari awal sampai akhir gerakan. Hal ini dilakukan untuk mengukur kemampuan anak.

Di akhir pembelajaran peneliti melakukan diskusi dengan anak-anak mengenai kegiatan yang telah dilakukan. Setelah itu dilanjutkan dengan bernyanyi, berdo'a, memberi salam dan pulang.

\section{c. Observasi}

Observasi pada siklus II pertemuan ketiga ini berpedoman pada lembar observasi yang telah disusun. Hasil pengamatan menunjukkan bahwa pada kegiatan meningkatkan kecerdasan kinestetik anak melalui tarian sabilulungan mix yamko rambe yamko terjadi peningkatan yang lebih baik dibandingkan dengan siklus I.

Berdasarkan hasil observasi maka tergambar bagaimana keadaan anak pada saat pembelajaran. Banyak aspek dari lembar observasi yang hasilnya sudah sesuai dengan yang diharapkan. Hasil Observasi dari pertemuan ketiga pada siklus II ini kecerdasan kinestetik anak sudah sesuai target yang diharapkan oleh peneliti yaitu $75 \%$.

\section{d. Refleksi}

Dengan melihat hasil akhir dari siklus II dan berdasarkan hasil pengamatan serta diskusi dengan kolabolator, kegiatan yang dilaksanakan pada siklus II pertemuan pertama, pertemuan kedua dan pertemuan ketiga sudah menunjukkan hasil yang signifikan. Kecerdasan kinestetik anak kelompok B telah mengalami peningkatan. Semua anak telah mencapai batas keberhasilan belajar yang optimal yaitu $75 \%$. Jika dilihat dari hasil yang diperoleh skor yang diperoleh dari data hasil observasi kecerdasan kinestetik anak siklus
II terhadap 14 responden secara keseluruhan didapat skor minimum 24, skor maksimum 48 dan presentase yang diperoleh 90.

Serangkaian pelaksanaan penelitian tindakan yang dilakukan pada pra penelitian, siklus I dan siklus II memperhatikan hasil intervensi tindakan yang diharapkan dan penelitian tindakan ini yaitu kecerdasan kinestetik anak usia56 tahun. Kemampuan ini ditujukan dengan anak dapat meningkatkan kecerdasan kinestetik melalui pembelajaran tari kreatif sabilulungan yang digabung dengan musik yamko rambe yamko.

Setelah dilakukan kegiatan gerakan tarian yang diberikan mulai dari tindakan pra siklus, siklus I sampai dengan dilakukannya tindakan siklus II telah diperoleh dari hasil data observasi. Kegiatan observasi ini dilakukan oleh peneliti dan kolabolator selama kegiatan gerakan tarian dilaksanakan. Peneliti bersama dengan kolabolator mengamati jalannya proses pembelajaran yang sedang berlangsung apakah telah sesuai dengan yang sudah direncanakan sebelumnya.

Kegiatan pengamatan yang selalu dilakukan bersama dengan anak-anak pada awal kegiatan pagi adalah dengan melakukan kegiatan bercakap-cakap, serta memberikan contoh gerakan yang akan dilakukan oleh anak. Hasil pengamatan yang didapat oleh peneliti dan kolabolator menunjukkan bahwa pada kecerdasan kinestetik ini pada siklus I belum memperoleh hasil yang maksimal, meskipun secara garis besar sudah mengalami peningkatan dari tahap pra siklus, sehingga peneliti dan kolabolator sepakat untuk melanjutkan ke tahap siklus II.

Peningkatan yang terjadi pada siklus II ini dapat dilihat dari kemampuan anak melakukan gerakan tarian yang sesuai dan dapat mengikuti gerakan sesuai dengan irama musik. Dari hasil analisis data pada tahap siklus II sudah cukup baik, dengan rumus peningkatan persentase kecerdasan 
kinestetik anak pada siklus II sebesar 90 \%. Dari data tersebut dapat disimpulkan bahwa kecerdasan kinestetik anak usia 5-6 tahun dapat ditingkatkan melalui sabilulungan mix yamko rambe yamko dance.

Berdasarkan hasil analisis data dengan menggunakan kenaikan presentase diketahui bahwa analisis dan siklus I diperoleh hasil peningkatan kecerdasan kinestetik pada siklus I $68 \%$ terhadap pra siklus dan siklus II sebesar $90 \%$ terhadap siklus I. Hasil tersebut menunjukkan kesesuaian dengan hipotesis tindakan yaitu kecerdasan kinestetik dapat ditingkatkan melaluisabilulungan mix yamko rambe yamko dance. Maka kecerdasan kinestetik anak kelompok Bdi KB-TK Assaid Larangan Indah Tangerang dapat ditingkatkan.

Dari hasil yang didapatkan dengan demikian dapat dinyatakan bahwa kegiatan pembelajaran tari kreatif sabilulungan yang digabung dengan musik yamko rambe yamko dapat meningkatkan kecerdasan kinestetik anak usia5-6 tahun.

\section{Hasil Observasi Siklus}

\begin{tabular}{|c|c|c|c|c|c|c|c|c|c|c|}
\hline \multirow[t]{2}{*}{ No } & \multirow[t]{2}{*}{ Nama } & \multicolumn{9}{|c|}{ Indikator } \\
\hline & & 1 & 2 & 3 & 4 & 5 & 6 & 7 & 8 & 9 \\
\hline 1 & Arkh & 4 & 4 & 4 & 3 & 4 & 4 & 3 & 3 & 3 \\
\hline 2 & Bel & 4 & 4 & 4 & 3 & 4 & 4 & 3 & 3 & 3 \\
\hline 3 & Cha & 4 & 4 & 4 & 3 & 4 & 4 & 3 & 3 & 3 \\
\hline 4 & Aul & 4 & 4 & 4 & 4 & 4 & 4 & 3 & 3 & 3 \\
\hline 5 & And & 4 & 4 & 4 & 4 & 4 & 4 & 4 & 4 & 4 \\
\hline 6 & Fat & 4 & 4 & 4 & 4 & 4 & 4 & 4 & 4 & 3 \\
\hline 7 & $\mathrm{Zi}$ & 4 & 3 & 4 & 3 & 4 & 4 & 2 & 3 & 4 \\
\hline 8 & Wan & 4 & 4 & 4 & 4 & 4 & 4 & 4 & 4 & 4 \\
\hline 9 & Yas & 2 & 2 & 2 & 2 & 2 & 2 & 2 & 2 & 2 \\
\hline 10 & Tsa & 4 & 4 & 4 & 3 & 4 & 4 & 3 & 3 & 4 \\
\hline 11 & Rai & 4 & 4 & 4 & 4 & 4 & 4 & 4 & 4 & 4 \\
\hline 12 & Ark & 4 & 4 & 4 & 3 & 4 & 4 & 3 & 2 & 4 \\
\hline 13 & Faj & 4 & 3 & 3 & 3 & 3 & 4 & 2 & 2 & 3 \\
\hline 14 & Vid & 4 & 4 & 4 & 4 & 4 & 4 & 4 & 4 & 4 \\
\hline \multicolumn{2}{|c|}{ Jumlah } & $\begin{array}{l}5 \\
0\end{array}$ & $\begin{array}{l}4 \\
8\end{array}$ & $\begin{array}{l}4 \\
9\end{array}$ & $\begin{array}{l}4 \\
4\end{array}$ & $\begin{array}{l}4 \\
9\end{array}$ & $\begin{array}{l}5 \\
0\end{array}$ & $\begin{array}{l}4 \\
1\end{array}$ & $\begin{array}{l}4 \\
1\end{array}$ & $\begin{array}{l}4 \\
5\end{array}$ \\
\hline \multirow{2}{*}{\multicolumn{2}{|c|}{ Persentase }} & 8 & 8 & 8 & 7 & 8 & 8 & 7 & 7 & 8 \\
\hline & & 9 & 6 & 7 & 9 & 7 & 9 & 3 & 3 & 0 \\
\hline
\end{tabular}

\section{KESIMPULAN}

Berdasarkan hasil penelitian yang telah dilakukan, peneliti menyimpulkan sebagai berikut:

1. Sesuai hasil data yang diperoleh pada penelitian yang dilaksanakan di Taman Kanak-kanak Assaid Larangan Indah persentase kecerdasan kinestetik anak sebelum dilakukan tindakan yaitu sebesar 35\%. Berdasarkan hasil yang diperoleh masih sangat jauh dari yang dinginkan maka perlu dilakukan tindakan yaitu dengan menerapkan kegiatan tari kreatif (sunda papua).Setelah dilaksanakan tindakan menunjukkan peningkatan pada siklus 1 jika dibandingkan dengan pra siklus yaitu sebesar $68 \%$. Namun, karena hasil yang didapat belum sesuai dengan target maka perlu dilaksanakan siklus II dan hasilnya mengalami peningkatan sebesar yaitu $90 \%$. Sehingga penelitian ini dapat dinyatakan berhasil, karena hasil sesuai dengan target yang ditentukan oleh peneliti yaitu $75 \%$. Hasil tersebut menunjukkan kesesuaian dengan hipotesis tindakan yaitu kecerdasan kinestetik anak usia5-6 tahun di Taman Kanak-kanak Assaid Larangan Indah dapat ditingkatkan melalui tari kreatif (sunda papua).

2. Penerapan kegiatan tari kreatif dalam meningkatkan kecerdasan kinestetik ini, menggunakan tarian yang menggunakan musik sabilulungan yang digabungkan dengan musik yamko rambe yamko, dan langkah-langkah tarian diantaranya menggerakkan tangan ke samping atas kanan dan samping kiri secara bergantian, tangan di pinggang kemudian pinggul di goyang ke kanan dan ke kiri secara bergantian kemudian duduk, menggerakkan tangan ke samping kanan dan samping kiri secara bergantian, berdiri sambil mengambil wadah yang berisi bunga kemudian bunga tersebut di lempar sambil berputar.ambil bambu yang telah disiapkan, kemudian memukul bambu 
secara berirama dan bergantian, mengayunkan tangan dengan posisi mengepal sambil memegang bambu ke belakang dan ke depan, memukul bambu secara bergantian ke atas kanan dan kiri kemudian ke bawah kanan dan kiri, mengangkat kedua tangan ke atas dan ke bawah sambil membungkukkan badan ke bawah.

\section{REFERENSI}

Direktorat Jenderal Pendidikan Anak Usia Dini. 2013. Petunjuk Teknis Penyelenggaran Taman Kanak-kanak: Jakarta. Direktorat Pembinaan Pendidikan Anak usia Dini.

Eko Purnomo dan Yunita Aslianty. 2005. Mengembangkan Tari Kreatif Pada Anak Usia Dini : Jakarta. TP.

Gardner, Howard. 2013. Multiple Intelligences: Daras

Hilmi, J, Yusef. 2010. Cara Cerdas Menjadikan Anak Jadi Cerdas: Makalah seminar Smart Parenting.

https://brainly.co.id/tugas/186169

http://www.empetilu.top/2016/05/apa-

makna-yang-terkandung-pada-

lagu 19.html

https://id.wikipedia.org/wiki/Yamko_Ram be Yamko

Hurlock, Elizabeth. 1978. Perkembangan Anak. Jakarta : Erlangga.

Kunandar. 2011. Langkah Mudah Penelitian Tindakan Kelas Sebagai Pengembangan Profesi Guru: Jakarta. PT. Rajagrafindo Persada.

Muhammad Yaumi dan Nurdin Ibrahim. 2013. Kecerdasan Jamak Multiple Intelligences: Jakarta. Kencana Prenadamedia.
Mulyani, Novi. 2016. Pendidikan Seni Tari Anak Usia Dini: Yogyakarta. Penerbit Gava Media.

Munandar, Utami. 1999. Pengembangan Kreativitas Anak Berbakat: Jakarta. Rineka Cipta.

Purwanto, Ngalim. 2007. Psikologi Pendidikan: Bandung. PT Remaja Rosdakarya

Ramelan, Purwati. 2010. Merangsang IQ Anak 4-9 Tahun Dosis Tinggi: Yogyakarta. Pustaka Widyatama.

Siswanto, Igrea. 2008. Mendidik Anak dengan Permainan Kreatif : Yogyakarta: PBMR ANDI, n.d.

Sudaryono. 2013. Pengembangan Instrumen Penelitian Pendidikan. Yogyakarta: Graha Ilmu.

Sujiono, Nurani Yuliani. 2013. Konsep Dasar Pendidikan Anak Usia Dini: Jakarta. Rineka Cipta.

Sunarto, Agung, Hartono. 1999. Perkembangan Peserta Didik: Jakarta. Rineka Cipta.

Susanto, Ahmad. 2012. Perkembangan Anak Usia Dini: Jakarta. Kencana Prenada Media Group.

Suyadi. 2010. Psikologi Belajar PAUD, (Yogyakarta : PT. Pusta Insan Madani.

Yulianti, 1996. Seni Gerak: Jakarta.

Widia Pekerti, dkk. 2007. Pendidikan Seni Musik Tari Drama : Jakarta. Universitas Terbuka.

Wiriaatmaja. 2010. Rochiati, Metode Penelitian Tindakan Kelas, (Bandung: PT. Remaja Rosdakarya. 